\title{
Artificial Light Enhances Red Pigmentation, but Not Ripening, of Harvested 'Anna' Apples
}

\author{
Yolanta Saks, Lilian Sonego, and Ruth Ben-Arie \\ Department of Fruit and Vegetable Storage, Agricultural Research \\ Organization, The Volcani Center, P.O.B. 6, Bet Dagan 50-250, Israel
}

Additional index words. temperature, ethylene, Malus domestica

\begin{abstract}
Mature-green 'Anna' apples (Malus domestics Borkh.) reddened after harvest as a result of exposure to continuous cool-white fluorescent light. Color development was most rapid at $20 \mathrm{C}$ but most intense at $13 \mathrm{C}$. At $2 \mathrm{C}$, although the induction of red pigmentation was the slowest, a $72-\mathrm{hr}$ exposure rendered color not significantly different from that of red, commercially harvested fruit. The development of color was light-intensity dependent, approaching saturation at $14.5 \mathrm{~W} \cdot \mathrm{m}^{-2}$ (at $\left.13 \mathrm{C}\right)$. No differences in fruit ripening were found between fruit that developed color under artificial light and red fruit from the commercial harvest, in spite of some stimulation of ethylene production during illumination.
\end{abstract}

One of the characteristics that determines the marketability of apples is fruit color (Walter, 1967). The highest quality apples have traditionally been grown in the northern, temperate zone, where color development is not a problem. However, apples are increasingly being grown in warmer regions of the world, where they are often-deficient in satisfactory color (Blankenship, 1987). A high level of ethylene has been associated with' the development of red pigmentation. Spraying with ethephon, an ethylene-releasing chemical, is a treatment adopted by some growers to improve fruit color (Blanpied et al., 1975) that, however, also leads to morerapid fruit softening (Blanpied et al., 1975; Chalmers et al., 1973).

Light and temperature, which are known to be of major importance in anthocyanin accumulation in the fruit on the tree (Blankenship, 1987; Diener and Neumann, 1981; Walter, 1967) and after harvest (Arakawa et al., 1985; Faragher and Brohier, 1984; Siegelman and Hendricks, 1957; Walter, 1967), have been suggested as possible means for improving red coloration without increasing fruit ripening (Looney, 1975). In spite of the results noted, almost no attention has been paid to the influence of conditions conducive to red coloration on other characteristics relating to fruit ripening. If the use of artificial illumination for improving the red pigmentation of apples is to become a commercial practice, then it will be of paramount importance to ascertain its effect on fruit ripening and senescence.

Received for publication 28 Dec. 1988. This is contribution no. 2551-E, 1988 series, from the Agricultural Research Organization, The Volcani Center, Bet Dagan, Israel. We thank Ezri Levy for his dedicated technical assistance. We also thank J.D. Klien for reading the manuscript and for his constructive comments. The cost of publishing this paper was defrayed in part by the payment of page charges. Under postal regulations, this paper therefore must be hereby marked advertisement solely to indicate this fact.
The objectives of the present study were to: 1) verify the efficacy of postharvest illumination with cool-white light in inducing the red coloration of mature-green 'Anna' apples; 2) assess the influence of effective illumination treatments on fruit ripening; and 3 ) determine the optimum conditions for treatment, taking both previous considerations into account.

'Anna', an Israeli cultivar, is suitable for a subtropical climate because of its low chilling requirement. However, it is character- ized by nonuniform (in time and coverage) color development, which, in very hot seasons, may be so delayed as to lead to fruit being harvested when it is overripe. The possibility of improving fruit color after harvest might lead to a greater uniformity in both fruit appearance and maturity.

Mature-green and red 'Anna' fruits, grown on the coastal plain of Israel, were harvested at the beginning of the commercial harvest (end of June). The green and red fruit were at a similar state of maturity at harvest, as judged by soluble solids content (SSC), flesh firmness, starch content, and the rate of ethylene evolution (see footnotes to Table 2). The green fruit was harvested mature to avoid the degradation of illumination-induced anthocyanin in subsequent darkness (Creasy, 1968). The harvested fruit was stored at 0C for 5 weeks in darkness and removed to higher temperatures when needed. Continuous coolwhite fluorescent light (Sylvania, 40-w tubes), as recommended by Bishop and Klein (1975), were used at three light intensities $\left(7.5,14.5\right.$, and $\left.17.5 \mathrm{~W} \cdot \mathrm{m}^{-2}\right)$ for illumination in chambers held at 2,13 , and $20 \pm$ $0.5 \mathrm{C}$. Twenty-five fruits were arranged in a box so that only one side of the fruit was illuminated in each treatment. Color development on both sides of the fruit was followed daily with a Gardner calorimeter (Gardner Instruments XL20 Calorimeter) to determine the increase in red (parameter "a") pigmentation, in parallel with the rate of ethylene emission. Ethylene emission was determined by enclosing a pair of apples in

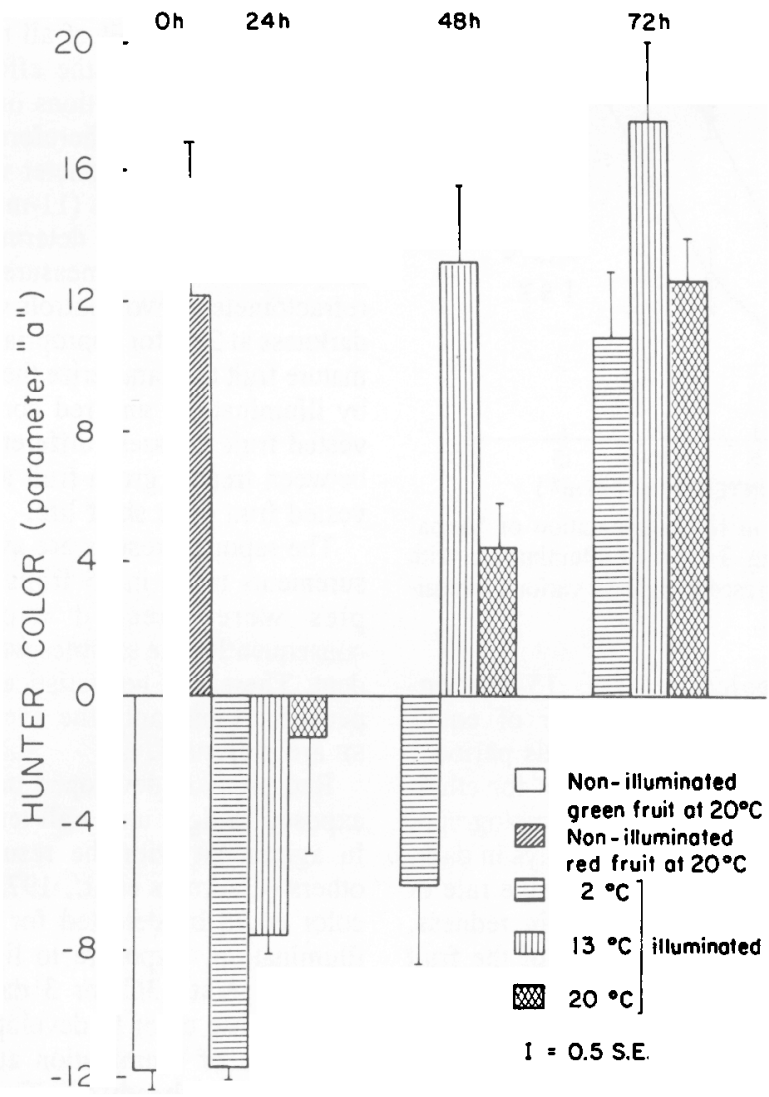

Fig. 1. Change in red pigmentation of 'Anna' apples during 3 days of illumination with cool-white fluorescent light at $14.5 \mathrm{~W} \cdot \mathrm{m}^{-2}$, at 2,13 , or $20 \mathrm{C}$. 
Table 1. Effect of illumination with cool-white light for 3 days at two temperatures on red pigment development and ethylene evolution on 'Anna' apples harvested green $( \pm \mathrm{SE})^{2}$.

\begin{tabular}{|c|c|c|c|c|c|}
\hline \multirow{2}{*}{\multicolumn{2}{|c|}{ Illumination conditions }} & \multirow[b]{3}{*}{$\begin{array}{c}\text { Initial } \\
\text { fruit color }\end{array}$} & \multicolumn{2}{|c|}{ Hunter color } & \multirow{3}{*}{$\begin{array}{c}\text { Ethylene } \\
\text { production } \\
\left(\mu \mathrm{k} \cdot \mathrm{kg}^{-1} \cdot \mathrm{hr}^{-1}\right)\end{array}$} \\
\hline & & & \multirow{2}{*}{$\begin{array}{c}\text { Nonilluminated } \\
\text { cheek } \\
\text { (Hunter a) }\end{array}$} & \multirow[b]{2}{*}{$\begin{array}{l}\text { Illuminated } \\
\text { cheek }\end{array}$} & \\
\hline $\begin{array}{l}\text { Intensity } \\
\left(W \cdot m^{-2}\right)\end{array}$ & $\begin{array}{c}\text { Temp. } \\
\left({ }^{\circ} \mathrm{C}\right)\end{array}$ & & & & \\
\hline \multirow[t]{3}{*}{$\overline{14.5}$} & 2 & Green & $-8 \pm 1.2$ & $10 \pm 2.4$ & $52 \pm 9$ \\
\hline & 13 & Green & $-7 \pm 2.1$ & $16 \pm 2.7$ & $153 \pm 35$ \\
\hline & 20 & Green & $-8 \pm 1.0$ & $12 \pm 2.0$ & $78 \pm 18$ \\
\hline \multirow[t]{2}{*}{0} & 0 & Red & $-6 \pm 2.1$ & $13 \pm 4.9^{x}$ & $29 \pm 20$ \\
\hline & 0 & Green & $-8 \pm 1.2$ & $\ldots$ & $47 \pm 11$ \\
\hline
\end{tabular}

${ }^{2}$ Data shown are means of 25 replicates.

Measured after $5 \mathrm{hr}$ at $20 \mathrm{C}$.

'Sun-exposed cheek.

Table 2. Effect of 3 days of illumination with cool-white light at various temperatures on subsequent ripening of 'Anna' apple fruit during 3 days in darkness at 20C $( \pm \mathrm{SE})^{2 \mathrm{~s}}$

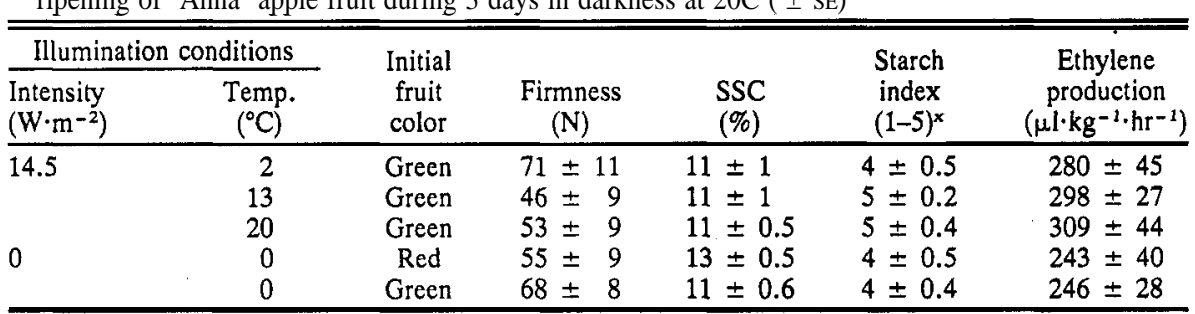

${ }^{2}$ Data shown are means of 25 replicate.

'Red mature fruit at harvest was characterized by 'a' +15 , firmness $74 \mathrm{~N}$, SSC $12 \%$, starch index 2.5 , and ethylene emission $25 \mu \mathrm{l} \cdot \mathrm{kg}^{-1} \cdot \mathrm{hr}^{-1}$. Green mature fruit at harvest was characterized by "a" -9 , firmness $87 \mathrm{~N}$, SSC $10 \%$, starch index 1.9 , and ethylene emission $8 \mu \mathrm{l}^{\mathrm{kg}} \mathrm{kg}^{-1} \cdot \mathrm{hr}^{-1}$.

${ }^{x} 1=$ high starch content, $5=$ low starch content.

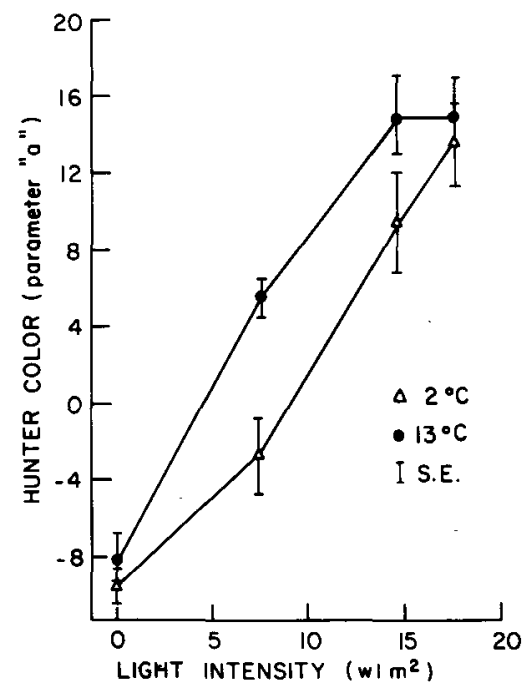

Fig. 2. Change in red pigmentation of 'Anna' apples following 3 days of illumination with cool-white fluorescent light at various intensities at 2 or $13 \mathrm{C}$.

hermetically sealed $1200 \pm 15$-ml containers for $1 \mathrm{hr}$ following $5 \mathrm{hr}$ of equilibration at 20C. At the end of this period 1 $\mathrm{ml}$ of the headspace was sampled for ethylene quantification with a gas chromatography. Illumination was followed by 3 days in darkness at 20C, at the end of which the rate of ethylene evolution, the change in redness, and fruit ripeness on both sides of the fruit were determined. All fruit manipulations necessary to measure fruit color and the rate of ethylene emission were performed at minimal light intensity $\left(0.5 \mathrm{~W} \cdot \mathrm{m}^{-2}\right)$, so as not to affect the color of the dark controls. This light intensity would not alter the effect of illumination even at the lowest light intensity treatment $\left(7.5 \mathrm{~W} \cdot \mathrm{m}^{-2}\right)$. For color determination, all fruit of a single treatment were removed from the illumination chamber for only 20 min and immediately thereafter returned to light. To measure the rate of ethylene evolution, fruit of all treatments were handled parallel and the effect of the temporarily altered conditions on this measurement, if any, were therefore similar in all treatments. A penetrometer was used to determine flesh firmness (1 1-mm tip); changes in starch content were determined by the IKI test; and SSC was measured with a hand refractometer. Two controls were held in the darkness at 20C for appropriate times: greenmature fruit to characterize the changes caused by illumination; and red commercially harvested fruit to assess differences in ripeness between treated green fruit and the red harvested fruit after shelf life.

The reported results are averages of measurements made in 25 fruits. The same apples were checked each time and, consequently, the samples were not independent. Therefore, no statistical analyses were performed and only the averages and their SE are presented.

Red pigment developed in the green fruit exposed to light under all tested conditions. In agreement with the results reported by others (Chalmers et al., 1973) no change in color could be detected for up to $20 \mathrm{hr}$ of illumination. Exposure to light intensity of $14 \mathrm{~W} \cdot \mathrm{m}^{-2}$ at $13 \mathrm{C}$ for 3 days allowed the most intense color to develop (Fig. 1). This advantage of illumination at $13 \mathrm{C}$ for color intensity was already significant after 2 days, but the fastest response was measured at 20C after 1 day of illumination. Redness devel- oped most slowly at $2 \mathrm{C}$, with a minimum of $40 \mathrm{hr}$ being required for measurable changes. In spite of the slow start, 3 days of illumination at $13 \mathrm{C}$ and $14.5 \mathrm{~W} \cdot \mathrm{m}^{-2}$ resulted in a degree of redness that did not differ significantly from that of the fruit illuminated at $20 \mathrm{C}$ or from the commercially harvested fruit. The fruit response to illumination was lightintensity dependent regardless of temperature until it reached an "a" value of $\approx 15$, close to that recorded for the red fruit on the tree (Fig. 2). At 13C, the red intensity was the highest at $14.5 \mathrm{~W} \cdot \mathrm{m}^{-2}$; greater illumination did not provide any additional benefits. Of particular interest are the results obtained for illumination at $2 \mathrm{C}$, considering the fact that in other reports illumination at low temperatures promoted red pigmentation only when interrupted by illumination at higher temperatures (Faragher, 1983).

Under all tested conditions, each treated fruit showed $100 \%$ red coverage on the side exposed to light. No color developed on the nonilluminated side of the fruit (Table 1 negative values). This result implies that by applying illumination, not only is it possible to avoid marketing of green 'Anna' fruit, but also to assure fruit that is uniformly red on $\approx 50 \%$ of its surface, whereas with present practice, red pigmentation covers from $\approx 10 \%$ to $50 \%$.

Under all tested conditions, fruit illumination followed by 3 days at $20 \mathrm{C}$ did not accelerate the ripening beyond that of commercially harvested fruit held in darkness for 3 days at 20C, as judged by the values for fruit firmness, SSC, starch content, and the rate of ethylene evolution (Table 2).

The high rate of ethylene evolution measured after illumination followed by 3 days in darkness at $20 \mathrm{C}$ was due mainly to the advance in ripening during storage at 20C (Tables 1,2). Even the high value obtained for ethylene evolution at $13 \mathrm{C}$ after illumination only (Table 1 ) was substantially lower after $5 \mathrm{hr}$ at $20 \mathrm{C}$ than that obtained for the commercially harvested fruit after 3 days at 20C (Table 2).

Considering the possibility that the slight increase in ethylene evolution during illumination might contribute to accelerated fruit ripening during post-illumination storage, an experiment was carried out to examine the storability of illuminated fruit. The fruit was illuminated at $13 \mathrm{C}$ for 2 days at a light intensity of $14.5 \mathrm{~W} \cdot \mathrm{m}^{-2}$, after which the ethylene evolution rate was $127 \mu \mathrm{l} \cdot \mathrm{kg}^{-1} \cdot \mathrm{hr}^{-1}$. The fruit was then transferred to $0 \mathrm{C}$ and ethylene evolution dropped to $29 \mu \mathrm{l} \cdot \mathrm{kg}^{-1} \cdot \mathrm{hr}^{-1}$. After 1 month in storage at $0 \mathrm{C}$, it remained at the same level and increased to 267 $\mu \mathrm{l} \cdot \mathrm{kg}^{-1} \cdot \mathrm{hr}^{-1}$ after 3 additional days at $20 \mathrm{C}$. The values for the green nonilluminated fruit were 46,26 , and $247 \mu \mathrm{l} \cdot \mathrm{kg}^{-1} \cdot \mathrm{hr}^{-1}$, respectively, for the above three dates of measurements.

We conclude that 'Anna' apples can reach satisfactory red pigmentation without detriment to ripening with 2 days of illumination at $13 \mathrm{C}$ or 3 days at $2 \mathrm{C}$ under cool-white fluorescent light at $14.5 \mathrm{~W} \cdot \mathrm{m}^{-2}$. Effectiveness at $2 \mathrm{C}$ has significance for the possibility 
of illuminating fruit in storage.

\section{Literature Cited}

Arakawa, O., Y. Hori, and R. Ogata. 1985. Relative effectiveness and interaction of ultraviolet-B, red and blue light in anthocyanin synthesis of apple fruit. Physiol. Plant 64:323-327.

Bishop, R.C. and R.M. Klein. 1975. Photo-pro. motion of anthocyanin synthesis in harvested apples. HortScience 10:126-127.

Blankenship, S.M. 1987. Night-temperature effects on rate of apple fruit maturation and fruit quality. Scientia Hort. 33:205-212.

Blanpied, G. D., C.G. Forshey, W.C. Stiles, D.W.

Green, W.J. Lord, and W.J. Bramlage. 1975.
Use of ethephon to stimulate red color without hastening ripening of McIntosh apples. J. Amer. Soc. Hort. Sci. 100:379-381.

Chalmers, D. J., J.D. Faragher, and J.W. Raff. 1973. Changes in anthocyanin synthesis as an index of maturity in red apple varieties. J. Hort. Sci. 48:387-392.

Creasy, L.L. 1968. The role of low temperature in anthocyanin synthesis in McIntosh apples. Proc. Amer. Soc. Hort. Sci. 93:713-724.

Diener, H.A. and W.D. Neumann. 1981. Influence of day and night temperature on anthocyanin synthesis in apple skin. Gartenbauwissenschaft 46:125-132.

Faragher, J.D. 1983. Temperature regulation of anthocyanin accumulation in apple skin. J. Expt. Bet. 34:1291-1298.

Faragher, J.D. and R.L. Brohier. 1984. Anthocyanin accumulation in apple skin during ripening: regulation by ethylene and phenylalanine ammonia-lyase. Scientia Hort. 22:89-96.

Looney, N.E. 1975. Control of ripening in 'McIntosh' apples. II. Effects of growth regulators and $\mathrm{CO}_{2}$ on fruit ripening, and storage life. J. Amer. Soc. Hort. Sci. 100:332-336.

Siegelman, H.W. and S.B. Hendricks. 1957. Photocontrol of anthocyanin synthesis in apple skin. Plant Physiol. 33:185-190.

Walter, T.E. 1967. Factors affecting fruit color in apples: a review of world literature. Rpt. E. Mailing Res. Sta. 1966:70-82.
HORTSCIENCE 25(5):549-552. 1990.

\section{Pathogenicity, Growth, and Sporulation of Mucor mucedo and Botrytis cinerea in Cold or CA Storage}

\author{
Andres A. Reyes ${ }^{1}$ \\ Agriculture Canada Research Station, Vineland Station, Ontario LOR \\ 2E0, Canada
}

Additional index words. $\quad$ postharvest diseases, mucor rot, gray mold, vegetables

\begin{abstract}
The virulence of Mucor mucedo (L.) Fr. (the cause of mucor rot) and Botrytis cinerea Pers. (gray mold) on vegetables stored at $13 \mathrm{C}$ for 7 days or $1 \mathrm{C}$ for $\mathbf{7 0}$ days varied with the host and controlled atmosphere (CA). M. mucedo was severely pathogenic at 13C to cucumber (Cucumis sativus L.), eggplant (Solarium melongena L. var. esculentum Nees), pepper (Capsicum annum L.), and tomato (Lycopersicon esculentum Mill.), but not to bean (Phaseolus vulgaris $\mathbf{L}$.). The fungus did not infect carrot (Daucus carota L. var. sativa DC.), celery (Apium graveolens L. var. dulce DC.), onion (Allium cepa L.), or parsnip (Pastinaca sativa L.) at 1C. B. cinerea was virulent on all of these crops at 13 or $1 \mathrm{C}$. The severity of mucor rot and gray mold on eggplant stored at $13 \mathrm{C}$ for 14 days was suppressed most in a $\mathrm{CA}$ of $7.5 \% \mathrm{CO}+1.5 \% \mathrm{O}_{2}$ and least in $1.5 \%$ $\mathbf{0}_{2}$, in comparison with the air control. Similarly, the growth and sporulation of each pathogen on eggplant-extract agar maintained at $13 \mathrm{C}$ for 4 or 14 days were suppressed most in $7.5 \% \mathrm{CO}+1.5 \% \mathrm{O}_{2}$; suppression was least in $1.5 \% \mathrm{O}_{2}$. The suppression of diseases on eggplant was highly correlated with the suppression of mycelial growth and sporulation of pathogens on agar.
\end{abstract}

Of the numerous reports of Mucor spp. causing decay of vegetables in cold storage, Mucor mucedo has not been listed as a pathogen in North America (Weimer and Harter, 1921; Butler, 1959; Smith et al., 1979). In 1981, in the United States, Moline and Millner (1981) first observed that M. mucedo caused a severe decay (hereafter referred to as mucor rot) of tomato fruit within 3 to 4 days after inoculation at 20C. There is little information regarding the suppression of mucor rot in controlled atmosphere (CA). In

Received for publication 15 May 1989. I acknowledge with thanks Diane M.L. Beaulieu-Aruvee (of my laboratory) for technical assistance and William A. Straver (Hort. Res. Inst. Ont.) for supplying the cucumber and tomato fruits. The cost of publishing this paper was defrayed in part by the payment of page charges. Under postal regulations, this paper therefore must be hereby marked advertisement solely to indicate this fact, ${ }^{1}$ Research Scientist. contrast, Botrytis cinerea has been reported frequently to cause gray mold on stored vegetables in Europe or North America (Smith range test, $P=0.05$ ).

${ }^{y}$ Dashes $=$ no data collected. et al., 1966; Adair, 1971; Geeson and Browne, 1980; Geeson et al., 1988). Gray mold was found to cause decay of vegetables shipped to the New York markets (Cappellini et al., 1987; Ceponis et al., 1985, 1986, 1987a, 1987b, 1988). In Ontario, Canada, Reyes and Smith (1986) have shown that $B$. cinerea caused severe gray mold on stored celery and that the disease was suppressed by $\mathrm{CA}$ storage at 0 to $1 \mathrm{C}$. Other studies have indicated that CA suppresses gray mold on cabbage (Adair, 1971; Geeson and Browne, 1980). The objectives of the present study were to 1) compare the pathogenicity of $M$. mucedo with that of $B$ cinerea on vegetables in storage, and 2) determine if CA suppresses these diseases on eggplant and reduces growth and sporulation of the pathogens on agar.

The vegetables used in this study were 2week-old (from anthesis), 10-cm-long, green bean pods (Phaseolus vulgaris L. C.W. Speculator); 8-week-old (from seeding), 4-cm-diameter carrot roots (Daucus carota L. var. sativa DC. cv. Spartan); 15-week-old (from seeding), 30-cm-long celery petioles (Apium graveolens L. var. dulce DC. CV. Tendercrisp); 2-week-old (from anthesis), 5-cm-diameter, green cucumber fruits (Cucumis sativus L. long type cv. Corona); 2-weekold (from anthesis), 5-cm-diameter eggplant fruits (Solarium melongena L. var. esculentum Nees narrow type CV. Tycoon); field-

Table 1. Pathogenicity of Mucor mucedo and Botrytis cinerea as indicated by average diameter of 10 replicate lesions on various vegetables stored at 1 or $13 \mathrm{C}$ for 70 and 7 days, respectively.

\begin{tabular}{|c|c|c|c|c|}
\hline \multirow[b]{3}{*}{ Vegetable } & \multicolumn{4}{|c|}{ Lesion diam $(\mathrm{cm})^{x . y}$} \\
\hline & \multicolumn{2}{|c|}{$1 \mathrm{C}$} & \multicolumn{2}{|c|}{$13 \mathrm{C}$} \\
\hline & $\begin{array}{l}\text { Mucor } \\
\text { mucedo }\end{array}$ & $\begin{array}{l}\text { Botrytis } \\
\text { cinerea }\end{array}$ & $\begin{array}{l}\text { Mucor } \\
\text { mucedo }\end{array}$ & $\begin{array}{l}\text { Botrytis } \\
\text { cinerea }\end{array}$ \\
\hline$\overline{\text { Bean }}$ & --- & $-\overline{-}$ & $0.0 \mathrm{f}$ & $4.0 \mathrm{~cd}$ \\
\hline Carrot & $0.0 \mathrm{~b}$ & $4.0 \mathrm{a}$ & $0.0 \mathrm{f}$ & $1.2 \mathrm{e}$ \\
\hline Celery & $0.0 \mathrm{~b}$ & $3.4 \mathrm{a}$ & $0.0 \mathrm{f}$ & $5.7 \mathrm{~b}$ \\
\hline Cucumber & -- & -- & $5.0 \mathrm{bc}$ & $5.4 \mathrm{~b}$ \\
\hline Eggplant & --- & --- & $8.5 \mathrm{a}$ & $5.8 \mathrm{~b}$ \\
\hline Onion & $0.0 \mathrm{~b}$ & $3.0 \mathrm{a}$ & $0.0 \mathrm{f}$ & $1.2 \mathrm{e}$ \\
\hline Parsnip & $0.0 \mathrm{~b}$ & $3.6 \mathrm{a}$ & --- & -- \\
\hline Pepper & -- & -- & $4.5 \mathrm{c}$ & $3.1 \mathrm{~d}$ \\
\hline Tomato & -- & --- & $8.8 \mathrm{a}$ & $3.6 \mathrm{~d}$ \\
\hline
\end{tabular}

${ }^{2}$ Means within each column followed by the same letter are not significantly different (Duncan's multiple 